\title{
Caffeic Acid Phenethyl Ester and Therapeutic Potentials
}

\author{
Ghulam Murtaza, ${ }^{1}$ Sabiha Karim, ${ }^{2}$ Muhammad Rouf Akram, ${ }^{3}$ Shujaat Ali Khan, \\ Saira Azhar, ${ }^{1}$ Amara Mumtaz, ${ }^{4}$ and Muhammad Hassham Hassan Bin Asad ${ }^{1}$ \\ ${ }^{1}$ Department of Pharmacy, COMSATS Institute of Information Technology, Abbottabad 22060, Pakistan \\ ${ }^{2}$ University College of Pharmacy, University of Punjab, Lahore 54000, Pakistan \\ ${ }^{3}$ Department of Pharmacy, University of Sargodha, Sargodha 40100, Pakistan \\ ${ }^{4}$ Department of Chemistry, COMSATS Institute of Information Technology, Abbottabad 22060, Pakistan
}

Correspondence should be addressed to Ghulam Murtaza; gmdogar356@gmail.com and Sabiha Karim; sksabihakarim@gmail.com Received 6 February 2014; Revised 2 April 2014; Accepted 14 April 2014; Published 29 May 2014

Academic Editor: George Perry

Copyright (C) 2014 Ghulam Murtaza et al. This is an open access article distributed under the Creative Commons Attribution License, which permits unrestricted use, distribution, and reproduction in any medium, provided the original work is properly cited.

Caffeic acid phenethyl ester (CAPE) is a bioactive compound of propolis extract. The literature search elaborates that CAPE possesses antimicrobial, antioxidant, anti-inflammatory, and cytotoxic properties. The principal objective of this review article is to sum up and critically assess the existing data about therapeutic effects of CAPE in different disorders. The findings elaborate that CAPE is a versatile therapeutically active polyphenol and an effective adjuvant of chemotherapy for enhancing therapeutic efficacy and diminishing chemotherapy-induced toxicities.

\section{Introduction}

Caffeic acid phenethyl ester (CAPE) is a natural bioactive compound. It occurs in many plants [1]. It is acquired from propolis obtained through extraction from honeybee hives [2]. The chemical name of CAPE is 2-phenylethyl (2E)-3-(3,4dihydroxyphenyl)acrylate. It is also termed as phenylethyl caffeate or phenethyl caffeate. Its molecular formula is $\mathrm{C}_{17} \mathrm{H}_{16} \mathrm{O}_{4}$ [3]. The chemical structure of CAPE is given in Figure 1. For the first time, Grunberger et al. identified this hydrophobic polyphenol [4]. This polyphenolic ester can also be synthesized by reacting caffeic acid with phenethyl alcohols [5-7]. CAPE is a polyphenol with hydroxyl groups within the catechol ring which is responsible for its crucial role in many biological activities [8]. The literature search showed an extensive research on the biological features of CAPE. The available studies narrate it as an effective moiety against various pathologies such as infections, oxidative stress, inflammation, cancer, diabetes, neurodegeneration, and anxiety $[3,5-8]$. These therapeutic characteristics of CAPE have been summarized in this review article.

\section{Activities of CAPE}

Large number of studies has been conducted on various features of the biological and pharmacological activities of CAPE and its mode of action. Some of them are summarized below.

2.1. Antimicrobial Activity of CAPE. There are many studies which demonstrate the antimicrobial activity of CAPE against Enterococcus faecalis, Listeria monocytogenes, Staphylococcus aureus [9-11], and Haemophilus influenzae showing that RNA, DNA, and cellular proteins are possible targets of CAPE [9, 12]. Thus, dietary intake of CAPE is useful for the treatment of sore throat, common cold, and wound. There is evidence that CAPE possesses promising fungicidal activity on fungi infecting tomato without causing any harm to the fruit [13]. Moreover, poly(lactic-co-glycolic acid) (PLGA) sutures containing CAPE have been proposed to have antibacterial activity against Staphylococcus aureus and Escherichia DH5 $\alpha$ bacteria; this activity of CAPE was attributed to the synthesis of reactive oxygen species (ROS) 
<smiles>O=C(/C=C/c1ccc(O)c(O)c1)OCCc1ccccc1</smiles>

FIgURE 1: Chemical structure of caffeic acid phenethyl ester [3].

that destroy the outer membrane of bacteria [14]. In recent studies [15-17], CAPE has been proposed as a valuable inhibitor of HIV-1 integrase; therefore, this polyphenol is believed to be a potential anti-HIV therapy. Fesen et al. reported that the integration step is efficiently inhibited by CAPE than the initial cleavage step by HIV-1 integrase [18]. In addition, CAPE and its esters, in a concentration range of 1.0 to $109.6 \mathrm{mM}$, have also been tested in an HCV replicon cell line of genotype $1 \mathrm{~b}$ and found effective against replication of hepatitis $\mathrm{C}$ virus suggesting it a promising anti-HCV compound [19].

2.2. Anti-Inflammatory Activity. The anti-inflammatory activity of CAPE has also been documented $[20,21]$ (Table 1). The mode of anti-inflammatory activity of CAPE involves the inhibition of arachidonic acid release from the cell membrane; it, in return, inhibits the COX-1 and COX-2 activity as well as suppresses the activation of gene responsible for COX-2 expression [22-25]. In carrageenin-induced inflammation, CAPE suppresses both exudate volume and leukocytes relocation [26-28].

Moreover, the immunosuppressive behavior of CAPE has been evaluated in T-cells [29] because generally the causative agent for inflammation is T-cells [25]. This discovery revealed the CAPE-mediated inhibition of initial and late steps in T-cell receptor-mediated T-cell activation [28] and thus proposed the mechanistic basis for the immunomodulatory and anti-inflammatory activities of CAPE. Furthermore, inhibition of both interleukin- (IL-) 2 gene transcription and the IL-2 synthesis by CAPE in stimulated T-cells was also observed. In Jurkat cells, binding with DNA and the activities of transcription factors, such as NF- $\kappa \mathrm{B}$, nuclear factor of activated cells (NFAT), and activator protein-1 (AP-1) were also characterized to examine the mode of inhibition of the transcription phase by CAPE [29-32]. The results elaborated the CAPE-mediated inhibition of NF- $\kappa$ Bdependent transcription showing no effect on the disposition of IB $\kappa \mathrm{B}$ (cytoplasmic NF- $\kappa \mathrm{B}$ inhibitory protein). In CAPEtreated Jurkat cells, there was restricted binding of NF- $\kappa \mathrm{B}$ to DNA and transcriptional activity of a Gal4-p65 hybrid protein. In addition, CAPE-mediated inhibition of binding with DNA and transcriptional activity of NFAT in CAPEtreated Jurkat cells was also seen [29].

For the assessment of CAPE effects, Sanghyum and SeokJai used human neutrophils activated by lipopolysaccharide [33]. The results of this study elaborated the CAPE-mediated inhibition of the production of TNF- $\alpha$ and IL- 6 factors. Moreover, the attenuation of phosphorylation potentials of ERK1/2 and JNK was also observed. As a conclusion, these
TABLE 1: Various activities and molecular targets of CAPE.

\begin{tabular}{lccc}
\hline Number & Activity & $\begin{array}{c}\text { Molecular targets } \\
\text { of CAPE }\end{array}$ & References \\
\hline 1 & Antioxidant & ROS & {$[22,55,86,97-103]$} \\
2 & Anti-inflammatory & NF- $\kappa$ B, NFAT, and & {$[4,23,38,104-106]$} \\
3 & Anticarcinogenic & AP-1 & {$[4,38,92,107,108]$} \\
4 & Antiviral & HIV -1 integrase & {$[55]$} \\
5 & Immunomodulator & NF- $\kappa$ B & {$[4,109]$} \\
6 & Antihepatotoxic & CYP2El & {$[93]$} \\
7 & Neuroprotective & ROS & {$[110]$} \\
8 & Antiatherosclerotic & NF- $\kappa$ B & {$[95]$} \\
\hline
\end{tabular}

TABLE 2: Cytotoxicity studies of CAPE in different cells.

\begin{tabular}{lcc}
\hline Number & Cells & References \\
\hline 1 & Human pancreatic cancer cells & {$[35]$} \\
2 & Human colon cancer cells & {$[36]$} \\
3 & C6 glioma cells & {$[37]$} \\
\hline
\end{tabular}

outcomes show the potential usage of CAPE for controlling inflammation caused by neutrophils.

In CAPE-treated gastric epithelial cell line (AGS), an obstruction was observed in cytokine- and mitogenprovoked NF- $\kappa \mathrm{B}$ and AP-1 expression [34]. Additionally, CAPE inhibited the $H$. pylori-provoked cell proliferation, H. pylori-induced COX-2 expression, and synthesis of the cytokines, TNF-a, and IL-8. These results are potential insights into the anticancer and anti-inflammatory activities of CAPE.

2.3. Cytotoxicity of CAPE. An extensive literature is available regarding cytotoxicity studies of CAPE as documented in Tables 1 and 2. In the presence of CAPE, human pancreatic and colon cancer cells undergo apoptosis $[35,36]$. The in vitro and in vivo studies reveal the growth inhibition of C6 glioma cells by CAPE [37].

There are many evidences [38-42] which elaborate the antiproliferation activity of CAPE. For normal cellular proliferation, adequate levels of nuclear factor (NF)- $\kappa$ B activity must be maintained. In some cancers, elevated activation of NF- $\kappa \mathrm{B}$ is observed. To obstruct the NF- $\kappa \mathrm{B}$ activation phenomenon, CAPE has been proved to be effective chemopreventive agent $[38,42]$. Nutritional ingestion of CAPE may thus be valuable for patients whose tumors express steadily elevated levels of activated NF- $\kappa \mathrm{B}$, for instance, squamous head and neck carcinomas. It has been reported that CAPE render antitumor features [43] devoid of causing cytotoxicity to normal cells [44]. Su et al. proposed that cytotoxicity of CAPE is directly related to its apoptotic effect [45].

The antitumor activity of CAPE has been investigated to reveal its influence on cancer development including angiogenesis, tumor invasion, and metastasis. Liao et al. carried out a cytotoxicity study of CAPE in colon adenocarcinoma cells (CT26) and reported a dose-dependent 
TABLE 3: Applications of caffeic acid phenethyl ester against chemotherapy-induced toxicities.

\begin{tabular}{|c|c|c|c|c|}
\hline Number & Toxicity inducing drugs & Toxicity & Subject & References \\
\hline 1 & \multirow{4}{*}{ Doxorubicin toxicity } & Nephrotoxicity & Rats & {$[111]$} \\
\hline 2 & & Cardiotoxicity & Rats & {$[112]$} \\
\hline 3 & & Neuronal oxidant injury & Rats & {$[113]$} \\
\hline 4 & & Medulloblastoma cell toxicity & Human & {$[114]$} \\
\hline 5 & \multirow{5}{*}{ Cisplatin toxicity } & Nephrotoxicity & Rats & {$[63]$} \\
\hline 6 & & Bone marrow cell toxicity & Rats & {$[115]$} \\
\hline 7 & & Hepatotoxicity & Rats & {$[116]$} \\
\hline 8 & & Hepatotoxicity & Rats & {$[117]$} \\
\hline 9 & & Ototoxicity & Rats & {$[114]$} \\
\hline 10 & \multirow{7}{*}{ Methotrexate toxicity } & Neuronal oxidant injury & Human & {$[118]$} \\
\hline 11 & & Nephrotoxicity & Rats & {$[119]$} \\
\hline 12 & & Cerebellar oxidative stress & Rats & {$[120]$} \\
\hline 13 & & Testicular toxicity & Rats & {$[121]$} \\
\hline 14 & & Nephrotoxicity & Rats & {$[122]$} \\
\hline 15 & & Hepatorenal oxidative injury & Rats & {$[123]$} \\
\hline 16 & & Hepatorenal oxidative injury & Rats & {$[124]$} \\
\hline 17 & Bleomycin toxicity & Lung fibrosis & Rats & {$[124,125]$} \\
\hline 18 & Tamoxifen toxicity & Hepatotoxicity & Rats & {$[126]$} \\
\hline
\end{tabular}

decline in cell viability [46]. Moreover, there was reduction in both expression of matrix metalloproteinase and production of vascular endothelial growth factor from CAPEtreated CT26 cells resulting in the reduced angiogenesis and metastasis [47]. These observations provide insight into the promising antimetastatic feature of CAPE. In addition, Song et al. reported that antiangiogenic property of CAPE was also accounted for its anti-inflammatory effect because angiogenesis and chronic inflammation depend on each other [48]. An anti-inflammatory response is obtained by blockage of angiogenesis [49-51]. As far as mode of anticancer activity of CAPE is concerned, CAPE is capable of (i) inhibiting the xanthine oxidase which can metabolize both purine and pyrimidine bases and obstruct the nucleotide production pathway [52-54]; (ii) suppressing 5-lipoxygenase [55]; (iii) inhibiting the tumor promoter-mediated oxidative responses in the culture of HeLa cells [56]; (iv) inhibiting the azoxymethane-provoked colonic preneoplastic lesions and enzymatic processes related to colon carcinogenesis [44]; (v) inducing apoptosis [57]; and (vi) modulating the redox state of the cells $[51,58-60]$.

2.4. CAPE against Chemotherapy- and Irradiation-Induced Toxicities. Due to free radical formation and oxidant injury, many drugs used for the treatment of cancer destroy the physiological homeostasis of many organs, such as kidneys and liver [61, 62]. It reduces therapeutic efficacy of anticancer drugs and produces undesired effects, such as doxorubicin, and cisplatin causes nephrotoxicity, while tamoxifen produces hepatotoxicity. Methotrexate activates the NF- $\kappa \mathrm{B}$ which causes mucosal barrier injury. These side effects limit their use as anticancer chemotherapy. Table 3 lists various studies conducted to explore the role of CAPE in minimizing
TABLE 4: Applications of caffeic acid phenethyl ester against chemotherapy-induced toxicities of tumor cells.

\begin{tabular}{lccc}
\hline Number & Toxicity & Subject & References \\
\hline 1 & Lung injury & Rats & {$[127]$} \\
2 & Medulloblastoma cell toxicity & Rats & {$[128]$} \\
3 & Ileal mucosal toxicity & Rats & {$[75]$} \\
4 & Normal lung fibroblast and lung & Rats & {$[129]$} \\
\hline
\end{tabular}

undesired effects of some anticancer drugs, that is, doxorubicin, cisplatin, methotrexate, bleomycin, and tamoxifen. The usage of CAPE suppresses free radical formation [63]; thus chemotherapy-induced toxicities are diminished. Moreover, CAPE inhibits the NF- $\kappa$ B factor which amplifies the susceptibility of intestinal epithelial cells to anticancer drugs, preferably methotrexate $[64,65]$. So, these studies present CAPE to be an effective adjuvant of chemotherapy for enhancing therapeutic efficacy and diminishing chemotherapy-induced toxicities.

The usage of CAPE against irradiation-induced toxicities of tumor cells has also been done and very promising results are seen (Table 4). Many genes are affected by transcription factor NF- $\kappa \mathrm{B}$ resulting in various disorders, such as immune and inflammatory syndromes. The activation of $\mathrm{NF}-\kappa \mathrm{B}$ induced by irradiation stimulates various undesired effects, such as an inflammatory response in the intestines. Since CAPE has emerged as an effective inhibitor of NF$\kappa \mathrm{B}$, CAPE has been applied in different animal models and cell lines to understand inflammatory phases after irradiation [66]. Table 4 enlists various studies which suggest that CAPE 
TABLE 5: Applications of caffeic acid phenethyl ester in radiosensitization of tumor cells.

\begin{tabular}{lcc}
\hline Number & Cell lines used & References \\
\hline 1 & Colorectal adenocarcinomas (CT26) & {$[67]$} \\
2 & $\begin{array}{c}\text { Lung cancer cells (A549) and normal lung } \\
\text { fibroblast cells (WI-38) }\end{array}$ & {$[130]$} \\
\hline
\end{tabular}

can promisingly avert the development of postirradiation inflammation.

For successful radiotherapy, the application of CAPE in radiosensitization of tumor cells has been studied (Table 5). By ionizing radiation, the increased death of CAPE treated cells has been reported [67]. Since CAPE is an effective inhibitor of NF- $\kappa \mathrm{B}$ and a stimulator of the functions of glutathione S-transferase, it drains GSH levels. Subsequently, tumor cells are radiosensitized due to this drainage.

2.5. Miscellaneous Activities of CAPE. The studies have demonstrated that CAPE possesses neuroprotective activity [6871]. CAPE can obstruct apoptosis in cerebellar granule cells [72], reduce ischemia/reperfusion-provoked cerebral injury $[73,74]$ and spinal cord ischemia/reperfusion injury [75], and avert different toxin-provoked neurotoxicity [69, 7679]. Moreover, CAPE efficiently suppresses NF $\kappa$ B activation [55], lipid peroxidation activity [38], lipoxygenase activities [80], protein tyrosine kinase activity [81], and ornithine decarboxylase activity [82].

As a result of cellular metabolism, reactive oxygen species (ROS) are generated. The representative examples of ROS include hydrogen peroxide $\left(\mathrm{H}_{2} \mathrm{O}_{2}\right)$, the superoxide anion, hydroxyl ion, and reactive nitrogen species, especially nitric oxide [83]. The enzymatic processes usually detoxify these ROS [84]. On the other hand, ROS build up if an imbalance is established between their synthesis and degradation resulting in oxidative stress. The excessive ROS can react to the macromolecules such as DNA resulting in some harmful responses [85]. Large research has been done to assess antioxidant role of CAPE $[10,86]$. The evidences show that CAPE is potent antioxidant which can scavenge ROS and protect the cell membrane against lipid peroxidation [87-91]. Some other studies elaborate immunomodulator $[4,38,92]$, antihepatotoxic [93], antiosteogenic [94], and antiatherosclerotic [95] (Table 1) role of CAPE. Moreover, Ucan et al. have proposed the effect of CAPE on bone healing in a rat model [96].

\section{Conclusion}

Considering the preceding literature, CAPE can be suggested to possess various activities, such as antimicrobial, antioxidant, anti-inflammatory, and cytotoxicity activities. The advance investigations are required about the clinical prospective toxicities of CAPE if it is going to be used as a therapeutic agent. Extensive literature is available on some research areas, but still some areas are very much less or not explored; therefore, further investigations to use this common and economic polyphenol for the best therapeutic treatment of ailments are required and proposed.

\author{
Abbreviations \\ CAPE: Caffeic acid phenethyl ester \\ ROS: Reactive oxygen species \\ HIV: Human immunodeficiency virus \\ HCV: Hepatitis $C$ virus \\ COX: Cyclooxygenase \\ IL: Interleukin \\ NF- $\kappa$ B: Nuclear factor \\ kappa-light-chain-enhancer of activated \\ $\mathrm{B}$ cells \\ NFAT: Nuclear factor of activated cells \\ AP-1: Activator protein-1 \\ $\mathrm{IB} \kappa \mathrm{B}: \quad$ Cytoplasmic NF- $\kappa \mathrm{B}$ inhibitory protein \\ ERK: Extracellular signal-regulated protein \\ kinases \\ JNK: c-Jun $\mathrm{NH}_{2}$-terminal kinase \\ TNF: Tumor necrosis factor \\ GSH: Glutathione \\ $\mathrm{H}_{2} \mathrm{O}_{2}$ : Hydrogen peroxide.
}

\section{Conflict of Interests}

The authors declare that there is no conflict of interests regarding the publication of this paper.

\section{Acknowledgments}

The authors are very thankful to Imran Tariq, Hafiz Muhammad Irfan Nazar, and Kalsoom Farzana for their kind help in the preparation of this review article.

\section{References}

[1] J. Metzner, H. Beckemeier, M. Paintz, and E. Schneidewind, "Zur antimikrobieller Wirksamkeit von Porpolis und Propolisinhaltstoffen," Pharmazie, vol. 34, pp. 97-102, 1979.

[2] V. Bankova, "Chemical diversity of propolis makes it a valuable source of new biologically active compounds," Journal of ApiProduct and ApiMedical Science, vol. 1, pp. 23-28, 2009.

[3] S. Kumazawa, M.-R. Ahn, T. Fujimoto, and M. Kato, "Radicalscavenging activity and phenolic constituents of propolis from different regions of Argentina," Natural Product Research, vol. 24, no. 9, pp. 804-812, 2010.

[4] D. Grunberger, R. Banerjee, K. Eisinger et al., "Preferential cytotoxicity on tumor cells by caffeic acid phenethyl ester isolated from propolis," Experientia, vol. 44, no. 3, pp. 230-232, 1988.

[5] H.-C. Chen, J.-H. Chen, C. Chang, and C.-J. Shieh, “Optimization of ultrasound-accelerated synthesis of enzymatic caffeic acid phenethyl ester by response surface methodology," Ultrasonics Sonochemistry, vol. 18, no. 1, pp. 455-459, 2011.

[6] H.-C. Chen, H.-Y. Ju, Y.-K. Twu et al., "Optimized enzymatic synthesis of caffeic acid phenethyl ester by RSM," New Biotechnology, vol. 27, no. 1, pp. 89-93, 2010. 
[7] A. Kurata, Y. Kitamura, S. Irie et al., "Enzymatic synthesis of caffeic acid phenethyl ester analogues in ionic liquid," Journal of Biotechnology, vol. 148, no. 2-3, pp. 133-138, 2010.

[8] X. Wang, S. Stavchansky, P. D. Bowman, and S. M. Kerwin, "Cytoprotective effect of caffeic acid phenethyl ester (CAPE) and catechol ring-fluorinated CAPE derivatives against menadione-induced oxidative stress in human endothelial cells," Bioorganic and Medicinal Chemistry, vol. 14, no. 14, pp. 4879-4887, 2006.

[9] N. Kishimoto, Y. Kakino, K. Iwai, K. Mochida, and T. Fujita, "In vitro antibacterial, antimutagenic and anti-influenza virus activity of caffeic acid phenethyl esters," Biocontrol Science, vol. 10, no. 4, pp. 155-161, 2005.

[10] C. Velazquez, M. Navarro, A. Acosta et al., "Antibacterial and free-radical scavenging activities of Sonoran propolis," Journal of Applied Microbiology, vol. 103, no. 5, pp. 1747-1756, 2007.

[11] A. Kujumgiev, V. Bankova, A. Ignatova, and S. Popov, "Antibacterial activity of propolis, some of its components and their analogs," Pharmazie, vol. 48, no. 10, pp. 785-786, 1993.

[12] J. Serkedjieva, N. Manolova, and V. Bankova, "Anti-influenza virus effect of some propolis constituents and their analogues (esters of substituted cinnamic acids)," Journal of Natural Products, vol. 55, no. 3, pp. 294-297, 1992.

[13] A.-J. Ojeda-Contreras, J. Hernández-Martínez, Z. Domínguez et al., "Utilization of caffeic acid phenethyl ester to control Alternaria alternata rot in tomato (Lycopersicon esculentum Mill.) fruit," Journal of Phytopathology, vol. 156, no. 3, pp. 164173, 2008.

[14] H. S. Lee, S. Y. Lee, S. H. Park et al., "Antimicrobial medical sutures with caffeic acid phenethyl ester and their in vitro/in vivo biological assessment," MedChemComm, vol. 4, pp. 777782, 2013.

[15] T. R. Burke Jr., M. R. Fesen, A. Mazumder et al., "Hydroxylated aromatic inhibitors of HIV-1 integrase," Journal of Medicinal Chemistry, vol. 38, no. 21, pp. 4171-4178, 1995.

[16] A. A. Johnson, C. Marchand, and Y. Pommier, "HIV-1 integrase inhibitors: a decade of research and two drugs in clinical trial," Current Topics in Medicinal Chemistry, vol. 4, no. 10, pp. 10591077, 2004.

[17] Y. Pommier, A. A. Johnson, and C. Marchand, "Integrase inhibitors to treat HIV/AIDS," Nature Reviews Drug Discovery, vol. 4, no. 3, pp. 236-248, 2005.

[18] M. R. Fesen, K. W. Kohn, F. Leteurtre, and Y. Pommier, "Inhibitors of human immunodeficiency virus integrase," Proceedings of the National Academy of Sciences of the United States of America, vol. 90, no. 6, pp. 2399-2403, 1993.

[19] H. Shen, A. Yamashita, M. Nakakoshi et al., "Inhibitory effects of caffeic acid phenethyl ester derivatives on replication of hepatitis C virus," PLoS ONE, vol. 8, no. 12, Article ID e82299, 2013.

[20] S.-Y. Jo, N. Lee, S.-M. Hong, H. H. Jung, and S.-W. Chae, "Caffeic acid phenethyl ester inhibits diesel exhaust particle-induced inflammation of human middle ear epithelial cells via NOX4 inhibition," Annals of Otology, Rhinology, and Laryngology, vol. 122, pp. 595-600, 2013.

[21] F. M. da Cunha, D. Duma, J. Assreuy et al., "Caffeic acid derivatives: in vitro and in vivo anti-inflammatory properties," Free Radical Research, vol. 38, no. 11, pp. 1241-1253, 2004.

[22] P. Michaluart, J. L. Masferrer, A. M. Carothers et al., "Inhibitory effects of caffeic acid phenethyl ester on the activity and expression of cyclooxygenase- 2 in human oral epithelial cells and in a rat model of inflammation," Cancer Research, vol. 59, no. 10, pp. 2347-2352, 1999.

[23] Z. Orban, N. Mitsiades, T. R. Burke Jr., M. Tsokos, and G. P. Chrousos, "Caffeic acid phenethyl ester induces leukocyte apoptosis, modulates nuclear factor-kappa B and suppresses acute inflammation," NeuroImmunoModulation, vol. 7, no. 2, pp. 99-105, 2000.

[24] O. K. Mirzoeva and P. C. Calder, "The effect of propolis and its components on eicosanoid production during the inflammatory response," Prostaglandins Leukotrienes and Essential Fatty Acids, vol. 55, no. 6, pp. 441-449, 1996.

[25] K. W. Lee, K.-S. Chun, J.-S. Lee, K.-S. Kang, Y.-J. Surh, and H. J. Lee, "Inhibition of cyclooxygenase-2 expression and restoration of gap junction intercellular communication in H-rastransformed rat liver epithelial cells by caffeic acid phenethyl ester," Annals of the New York Academy of Sciences, vol. 1030, pp. 501-507, 2004.

[26] F. Borrelli, P. Maffia, L. Pinto et al., "Phytochemical compounds involved in the anti-inflammatory effect of propolis extract," Fitoterapia, vol. 73, no. 1, pp. S53-S63, 2002.

[27] M. Gabor and Z. Razga, "Effect of benzopyrone derivatives on simultaneously induced croton oil ear oedema and carrageenin paw oedema in rats," Acta Physiologica Hungarica, vol. 77, no. 3-4, pp. 197-207, 1991.

[28] G. M. Raso, R. Meli, G. di Carlo, M. Pacilio, and R. di Carlo, "Inhibition of inducible nitric oxide synthase and cyclooxygenase- 2 expression by flavonoids in macrophage J774A.1," Life Sciences, vol. 68, no. 8, pp. 921-931, 2001.

[29] W.-X. Zhao, L. Wang, J.-L. Yang, L.-Z. Li, W.-M. Xu, and T. $\mathrm{Li}$, "Caffeic acid phenethyl ester attenuates pro-inflammatory and fibrogenic phenotypes of LPS-stimulated hepatic stellate cells through the inhibition of NF- $\kappa \mathrm{B}$ signaling," Journal of Pharmacology, vol. 33, pp. 687-694, 2014.

[30] S. Akyol, M. Acar, Z. N. Ünal et al., "The effects of caffeic acid phenethyl ester (CAPE), royal jelly, and curcumin on gene expression of ADAMTS-1,-5, and -9 in OUMS-27 chondrosarcoma cells: a preliminary study," Annals of Paediatric Rheumatology, vol. 2, pp. 27-37, 2013.

[31] J.-Y. Lee, H.-J. Choi, T.-W. Chung, C.-H. Kim, H.-S. Jeong, and K.-T. Ha, "Caffeic acid phenethyl ester inhibits alpha-melanocyte stimulating hormone-induced melanin synthesis through suppressing transactivation activity of microphthalmia-associated transcription factor," Journal of Natural Products, vol. 76, no. 8, pp. 1399-1405, 2013.

[32] C. P. P. Chuu, H. P. Lin, M. F. Ciaccio et al., "Caffeic acid phenethyl ester suppresses the proliferation of human prostate cancer cells through inhibition of p70S6K and Akt signaling networks," Cancer Prevention Research, vol. 5, no. 5, pp. 788797, 2012.

[33] K. Sanghyum and K. Seok-Jai, "Effect of caffeic acid phenethyl ester on phagocytosis of septic neutrophil," Critical Care Medicine, vol. 40, no. 12, 2012.

[34] M. M. M. Abdel-Latif, H. J. Windle, B. S. El Homasany, K. Sabra, and D. Kelleher, "Caffeic acid phenethyl ester modulates Helicobacter pylori-induced nuclear factor-kappa B and activator protein-1 expression in gastric epithelial cells," British Journal of Pharmacology, vol. 146, no. 8, pp. 1139-1147, 2005.

[35] M.-J. Chen, W.-H. Chang, C.-C. Lin et al., "Caffeic acid phenethyl ester induces apoptosis of human pancreatic cancer cells involving caspase and mitochondrial dysfunction," Pancreatology, vol. 8, no. 6, pp. 566-576, 2008. 
[36] D. Xiang, D. Wang, Y. He et al., "Caffeic acid phenethyl ester induces growth arrest and apoptosis of colon cancer cells via the $\beta$-catenin/T-cell factor signaling," Anti-Cancer Drugs, vol. 17, no. 7, pp. 753-762, 2006.

[37] H.-C. Kuo, W.-H. Kuo, Y.-J. Lee, W.-L. Lin, F.-P. Chou, and T.H. Tseng, "Inhibitory effect of caffeic acid phenethyl ester on the growth of C6 glioma cells in vitro and in vivo," Cancer Letters, vol. 234, no. 2, pp. 199-208, 2006.

[38] K. Natarajan, S. Singh, T. R. Burke Jr., D. Grunberger, and B. B. Aggarwal, "Caffeic acid phenethyl ester is a potent and specific inhibitor of activation of nuclear transcription factor NF- $\kappa \mathrm{B}$," Proceedings of the National Academy of Sciences of the United States of America, vol. 93, no. 17, pp. 9090-9095, 1996.

[39] L. Zhang, H. Zhang, X. Zheng et al., "Structural basis for the inhibition of AKR1B10 by caffeic acid phenethyl ester (CAPE)," ChemMedChem, vol. 9, no. 4, pp. 706-709, 2014.

[40] H. C. Ho, H. C. Chang, C. T. Ting, C. Y. Kuo, and V. C. Yang, "Caffeic acid phenethyl ester inhibits proliferation and migration, and induces apoptosis in platelet-derived growth factor-BB-stimulated human coronary smooth muscle cells," Journal of Vascular Research, vol. 49, no. 1, pp. 24-32, 2011.

[41] T. Dorai and B. B. Aggarwal, "Role of chemopreventive agents in cancer therapy," Cancer Letters, vol. 215, no. 2, pp. 129-140, 2004.

[42] A. C. Bharti and B. B. Aggarwal, "Nuclear factor-kappa B and cancer: its role in prevention and therapy," Biochemical Pharmacology, vol. 64, no. 5-6, pp. 883-888, 2002.

[43] P. Komericki and B. Kränke, "Maculopapular exanthem from propolis: case report and review of systemic cutaneous and noncutaneous reactions," Contact Dermatitis, vol. 61, no. 6, pp. 353$355,2009$.

[44] K. Frenkel, H. Wei, R. Bhimani et al., "Inhibition of tumor promoter-mediated processes in mouse skin and bovine lens by caffeic acid phenethyl ester," Cancer Research, vol. 53, no. 6, pp. 1255-1261, 1993.

[45] Z.-Z. Su, J. Lin, M. Prewett, N. I. Goldstein, and P. B. Fisher, "Apoptosis mediates the selective toxicity of caffeic acid phenethyl ester (CAPE) toward oncogene-transformed rat embryo fibroblast cells," Anticancer Research, vol. 15, no. 5 B, pp. 1841-1848, 1995.

[46] H.-F. Liao, Y.-Y. Chen, J.-J. Liu et al., "Inhibitory effect of caffeic acid phenethyl ester on angiogenesis, tumor invasion, and metastasis," Journal of Agricultural and Food Chemistry, vol. 51, no. 27, pp. 7907-7912, 2003.

[47] M. L. Khalil, "Biological activity of bee propolis in health and disease," Asian Pacific Journal of Cancer Prevention, vol. 7, no. 1, pp. 22-31, 2006.

[48] Y. S. Song, E.-H. Park, J. J. Kyung, and C. Jin, "Inhibition of angiogenesis by propolis," Archives of Pharmacal Research, vol. 25, no. 4, pp. 500-504, 2002.

[49] W.-L. Lin, W.-H. Liang, Y.-J. Lee, S.-K. Chuang, and T.-H. Tseng, "Antitumor progression potential of caffeic acid phenethyl ester involving p75NTR in C6 glioma cells," Chemico-Biological Interactions, vol. 188, no. 3, pp. 607-615, 2010.

[50] N. Oršolić and I. Bašić, "Water-soluble derivative of propolis and its polyphenolic compounds enhance tumoricidal activity of macrophages," Journal of Ethnopharmacology, vol. 102, no. 1, pp. 37-45, 2005.

[51] G. Basini, L. Baioni, S. Bussolati et al., "Antiangiogenic properties of an unusual benzo[k,l]xanthene lignan derived from CAPE (Caffeic Acid Phenethyl Ester)," Investigational New Drugs, vol. 30, no. 1, pp. 186-190, 2012.
[52] G. Ozturk, Z. Ginis, S. Akyol, G. Erden, A. Gurel, and O. Akyol, "The anticancer mechanism of caffeic acid phenethyl ester (CAPE): review of melanomas, lung and prostate cancers," European Review for Medical and Pharmacological Sciences, vol. 16, pp. 2064-2068, 2012.

[53] H. M. Eid, D. Vallerand, A. Muhammad, T. Durst, P. S. Haddad, and L. C. Martineau, "Structural constraints and the importance of lipophilicity for the mitochondrial uncoupling activity of naturally occurring caffeic acid esters with potential for the treatment of insulin resistance," Biochemical Pharmacology, vol. 79, no. 3, pp. 444-454, 2010.

[54] T. Wang, L. X. Chen, W. M. Wu, Y. Long, and R. Wang, "Potential cytoprotection: antioxidant defence by caffeic acid phenethyl ester against free radical-induced damage of lipids, DNA, and proteins," Canadian Journal of Physiology and Pharmacology, vol. 86, no. 5, pp. 279-287, 2008.

[55] G. F. Sud'ina, O. K. Mirzoeva, M. A. Pushkareva, G. A. Korshunova, N. V. Sumbatyan, and S. D. Varfolomeev, "Caffeic acid phenethyl ester as a lipoxygenase inhibitor with antioxidant properties," FEBS Letters, vol. 329, no. 1-2, pp. 21-24, 1993.

[56] R. S. Bhimani, W. Troll, D. Grunberger, and K. Frenkel, "Inhibition of oxidative stress in HeLa cells by chemopreventive agents," Cancer Research, vol. 53, no. 18, pp. 4528-4533, 1993.

[57] M. Nomura, A. Kaji, W. Ma, K. Miyamoto, and Z. Dong, "Suppression of cell transformation and induction of apoptosis by caffeic acid phenethyl ester," Molecular Carcinogenesis, vol. 31, no. 2, pp. 83-89, 2001.

[58] C. Chiao, A. M. Carothers, D. Grunberger, G. Solomon, G. A. Preston, and J. C. Barrett, "Apoptosis and altered redox state induced by caffeic acid phenethyl ester (CAPE) in transformed rat fibroblast cells," Cancer Research, vol. 55, no. 16, pp. 35763583, 1995.

[59] S. K. Kudugunti, H. Thorsheim, M. S. Yousef, L. Guan, and M. Y. Moridani, "The metabolic bioactivation of caffeic acid phenethyl ester (CAPE) mediated by tyrosinase selectively inhibits glutathione S-transferase," Chemico-Biological Interactions, vol. 192, no. 3, pp. 243-256, 2011.

[60] S. K. Kudugunti, N. M. Vad, E. Ekogbo, and M. Y. Moridani, "Efficacy of Caffeic acid Phenethyl Ester (CAPE) in skin B16-F0 melanoma tumor bearing C57BL/6 mice," Investigational New Drugs, vol. 29, no. 1, pp. 52-62, 2011.

[61] G. M. Sulaiman, A. A. Al-Amiery, and R. Bagnati, “Theoretical, antioxidant and cytotoxic activities of caffeic acid phenethyl ester and chrysin," International Journal of Food Sciences and Nutrition, vol. 65, pp. 101-105, 2014.

[62] S. Akyol, Z. Ginis, F. Armutcu, G. Ozturk, M. Ramazan Yigitoglu, and O. Akyol, "The potential usage of caffeic acid phenethyl ester (CAPE) against chemotherapy-induced and radiotherapy-induced toxicity," Cell Biochemistry and Function, vol. 30, no. 5, pp. 438-443, 2012.

[63] S. Özen, Ö. Akyol, M. Iraz et al., "Role of caffeic acid phenethyl ester, an active component of propolis, against cisplatininduced nephrotoxicity in rats," Journal of Applied Toxicology, vol. 24, no. 1, pp. 27-35, 2004.

[64] A. Kizilay, M. T. Kalcioglu, E. Ozerol et al., "Caffeic acid phenethyl ester ameliorated ototoxicity induced by cisplatin in rats," Journal of Chemotherapy, vol. 16, no. 4, pp. 381-387, 2004.

[65] B. van't Land, N. M. A. Blijlevens, J. Marteijn et al., "Role of curcumin and the inhibition of NF-KB in the onset of chemotherapy-induced mucosal barrier injury," Leukemia, vol. 18, no. 2, pp. 276-284, 2004. 
[66] C. Linard, C. Marquette, J. Mathieu, A. Pennequin, D. Clarençon, and D. Mathé, "Acute induction of inflammatory cytokine expression after $\gamma$-irradiation in the rat: effect of an NF- $\kappa \mathrm{B}$ inhibitor," International Journal of Radiation Oncology Biology Physics, vol. 58, no. 2, pp. 427-434, 2004.

[67] Y.-J. Chen, H.-F. Liao, T.-H. Tsai, S.-Y. Wang, and M.-S. Shiao, "Caffeic acid phenethyl ester preferentially sensitizes CT26 colorectal adenocarcinoma to ionizing radiation without affecting bone marrow radioresponse," International Journal of Radiation Oncology Biology Physics, vol. 63, no. 4, pp. 1252-1261, 2005.

[68] S. Akyol, F. Armutçu, and M. R. Yiğitoğlu, “The medical usage of caffeic acid phenethyl ester (CAPE), an active compound of propolis, in neurological disorders and emergencies," Spatula DD, vol. 1, no. 1, pp. 37-42, 2011.

[69] X. Wei, Z. Ma, C. V. Fontanilla et al., "Caffeic acid phenethyl ester prevents cerebellar granule neurons (CGNs) against glutamate-induced neurotoxicity," Neuroscience, vol. 155, no. 4, pp. 1098-1105, 2008.

[70] M. E. Altuğ, Y. Serarslan, R. Bal et al., "Caffeic acid phenethyl ester protects rabbit brains against permanent focal ischemia by antioxidant action: a biochemical and planimetric study," Brain Research, vol. 1201, pp. 135-142, 2008.

[71] B. Özyurt, M. Güleç, H. Özyurt, F. Ekici, Ö. Atis, and A. Akbas, "The effect of antioxidant caffeic acid phenethyl ester (CAPE) on some enzyme activities in cisplatin-induced neuro toxicity in rats," European Journal of General Medicine, vol. 3, pp. 167172, 2006.

[72] R. Amodio, C. de Ruvo, A. Sacchetti et al., "Caffeic acid phenethyl ester blocks apoptosis induced by low potassium in cerebellar granule cells," International Journal of Developmental Neuroscience, vol. 21, pp. 379-389, 2003.

[73] K. Cagli, C. Bagci, M. Gulec et al., "In vivo effects of caffeic acid phenethyl ester on myocardial ischemia-reperfusion injury and apoptotic changes in rats," Annals of Clinical and Laboratory Science, vol. 35, no. 4, pp. 440-448, 2005.

[74] M. K. Irmak, E. Fadillioglu, S. Sogut et al., "Effects of caffeic acid phenethyl ester and alpha-tocopherol on reperfusion injury in rat brain," Cell Biochemistry and Function, vol. 21, no. 3, pp. 283289, 2003.

[75] O. Grémy, M. Benderitter, and C. Linard, "Caffeic acid phenethyl ester modifies the Th1/Th2 balance in ileal mucosa after $\gamma$-irradiation in the rat by modulating the cytokine pattern," World Journal of Gastroenterology, vol. 12, no. 31, pp. 4996-5004, 2006.

[76] C. V. Fontanilla, Z. Ma, X. Wei et al., "Caffeic acid phenethyl ester prevents 1-methyl-4-phenyl-1,2,3,6-tetrahydropyridineinduced neurodegeneration," Neuroscience, vol. 188, pp. 135-141, 2011.

[77] Z. Ma, X. Wei, C. Fontanilla et al., "Caffeic acid phenethyl ester blocks free radical generation and 6-hydroxydopamineinduced neurotoxicity," Life Sciences, vol. 79, no. 13, pp. 13071311, 2006.

[78] C. Noelker, M. Bacher, P. Gocke et al., "The flavanoide caffeic acid phenethyl ester blocks 6-hydroxydopamine- induced neurotoxicity," Neuroscience Letters, vol. 383, no. 1-2, pp. 39-43, 2005.

[79] M. Eşrefoǧlu, M. Gül, B. Ateş, and I. Yilmaz, “The ultrastructural and biochemical evidences of the beneficial effects of chronic caffeic acid phenethyl ester and melatonin administration on brain and cerebellum of aged rats," Fundamental and Clinical Pharmacology, vol. 24, no. 3, pp. 305-315, 2010.
[80] J. Laranjinha, O. Vieira, V. Madeira, and L. Almeida, "Two related phenolic antioxidants with opposite effects on vitamin E content in low density lipoproteins oxidized by ferrylmyoglobin: consumption vs regeneration," Archives of Biochemistry and Biophysics, vol. 323, no. 2, pp. 373-381, 1995.

[81] Y. Kimura, H. Okuda, and T. Okuda, "Studies on the activities of tannins and related compounds from medicinal plants and drugs. VII. Effects of extracts of leaves of Artemisia species, and caffeic acid and chlorogenic acid on lipid metabolic injury in rats fed peroxidized oil," Chemical and Pharmaceutical Bulletin, vol. 33, no. 5, pp. 2028-2034, 1985.

[82] Z. S. Z. Zai Sheng Zheng, G. Z. X. Guo Zhen Xue, D. Grunberger, and J. H. Prystowsky, "Caffeic acid phenethyl ester inhibits proliferation of human keratinocytes and interferes with the EGF regulation of ornithine decarboxylase," Oncology Research, vol. 7, no. 9, pp. 445-452, 1995.

[83] A. Kurek-Górecka, A. Rzepecka-Stojko, M. Górecki, J. Stojko, M. Sosada, and G. Świerczek-Zięba, "Structure and antioxidant activity of polyphenols derived from propolis," Molecules, vol. 19, pp. 78-101, 2014.

[84] P. Olczyk, P. Ramos, Bernaś et al., "Application of electron paramagnetic resonance spectroscopy to comparative examination of different groups of free radicals in thermal injuries treated with propolis and silver sulphadiazine," Evidence Based Complementary and Alternative Medicines, vol. 2013, Article ID 851940, 11 pages, 2013.

[85] P. Olczyk, G. Wisowski, K. Komosińska-Vassev et al., "Propolis modifies collagen types I and III accumulation in the matrix of burnt tissue," Evidence Based Complementary Alternative Medicines, vol. 2013, Article ID 423809, 10 pages, 2013.

[86] A. Russo, R. Longo, and A. Vanella, "Antioxidant activity of propolis: role of caffeic acid phenethyl ester and galangin," Fitoterapia, vol. 73, no. 1, pp. S21-S29, 2002.

[87] N. Yasui, E. Nishiyam, S. Juman et al., "Caffeic acid phenethyl ester suppresses oxidative stress in 3T3-L1 adipocytes.," Journal of Asian Natural Products Research, vol. 15, pp. 1189-1196, 2013.

[88] P. Olczyk, K. Komosińska-Vassev, K. Winsz-Szczotka, J. Stojko, K. Klimek, and E. Koźma, "Propolis induces chondroitin/dermatan sulphate and hyaluronic acid accumulation in the skin of burned wound," Evidence Based Complementary and Alternative Medicines, vol. 2013, Article ID 290675, 8 pages, 2013.

[89] H. S. Kavakli, O. Alici, C. Koca, A. Ilhan, and B. Isik, "Caffeic acid phenethyl ester decreases oxidative stress index in blunt spinal cord injury in rats," Hong Kong Journal of Emergency Medicine, vol. 17, no. 3, pp. 250-255, 2010.

[90] G. Serarslan, E. Altuğ, T. Kontas, E. Atik, and G. Avci, "Caffeic acid phenetyl ester accelerates cutaneous wound healing in a rat model and decreases oxidative stress," Clinical and Experimental Dermatology, vol. 32, no. 6, pp. 709-715, 2007.

[91] F. Ozguner, A. Altinbas, M. Ozaydin et al., "Mobile phoneinduced myocardial oxidative stress: protection by a novel antioxidant agent caffeic acid phenethyl ester," Toxicology and Industrial Health, vol. 21, no. 9, pp. 223-230, 2005.

[92] L. N. Shulman and E. Braunwold, "Cardiac effects of radiation therapy and chemotherapy," in Heart Disease: A Textbook of Cardiovascular Medicine, E. Braunwold, Ed., pp. 1799-1804, WB Saunders, Philadelphia, Pa, USA, 5th edition, 1997.

[93] K. J. Lee, J. H. Choi, T. Khanal, Y. P. Hwang, Y. C. Chung, and H. G. Jeong, "Protective effect of caffeic acid phenethyl ester against carbon tetrachloride-induced hepatotoxicity in mice," Toxicology, vol. 248, no. 1, pp. 18-24, 2008. 
[94] M. Erdem, D. Gulabi, C. Sen, S. A. Sahin, and E. Bozdag, "Effects of caffeic acid phenethyl ester and melatonin on distraction osteogenesis: an experimental study," SpringerPlus, vol. 3, pp. 813, 2014.

[95] K. Hishikawa, T. Nakaki, and T. Fujita, "Oral flavonoid supplementation attenuates atherosclerosis development in apolipoprotein E-deficient mice," Arteriosclerosis, Thrombosis, and Vascular Biology, vol. 25, no. 2, pp. 442-446, 2005.

[96] M. C. Ucan, M. Koparal, S. Ağaçayak et al., "Influence of caffeic acid phenethyl ester on bone healing in a rat model," Journal of International Medical Research, vol. 41, pp. 1648-1654, 2013.

[97] A. Gurel, F. Armutcu, S. Sahin et al., "Protective role of $\alpha$-tocopherol and caffeic acid phenethyl ester on ischemiareperfusion injury via nitric oxide and myeloperoxidase in rat kidneys," Clinica Chimica Acta, vol. 339, no. 1-2, pp. 33-41, 2004.

[98] U. Koltuksuz, S. Özen, E. Uz et al., "Caffeic acid phenethyl ester prevents intestinal reperfusion injury in rats," Journal of Pediatric Surgery, vol. 34, no. 10, pp. 1458-1462, 1999.

[99] E. Uz, S. Sögüt, S. Sahin et al., "The protective role of caffeic acid phenethyl ester (CAPE) on testicular tissue after testicular torsion and detorsion," World Journal of Urology, vol. 20, no. 4, pp. 264-270, 2002.

[100] A. Ilhan, U. Koltuksuz, S. Ozen, E. Uz, H. Ciralik, and O. Akyol, "The effects of caffeic acid phenethyl ester (CAPE) on spinal cord ischemia/reperfusion injury in rabbits," European Journal of Cardio-thoracic Surgery, vol. 16, no. 4, pp. 458-463, 1999.

[101] M. Çalikoglu, L. Tamer, N. Sucu et al., "The effects of caffeic acid phenethyl ester on tissue damage in lung after hindlimb ischemia-reperfusion," Pharmacological Research, vol. 48, no. 4, pp. 397-403, 2003.

[102] S. Son and B. A. Lewis, "Free radical scavenging and antioxidative activity of caffeic acid amide and ester analogues: structure-activity relationship," Journal of Agricultural and Food Chemistry, vol. 50, no. 3, pp. 468-472, 2002.

[103] C. V. Rao, D. Desai, B. Kaul, S. Amin, and B. S. Reddy, "Effect of caffeic acid esters on carcinogen-induced mutagenicity and human colon adenocarcinoma cell growth," Chemico-Biological Interactions, vol. 84, no. 3, pp. 277-290, 1992.

[104] T. Nagaoka, A. H. Banskota, Y. Tezuka, I. Saiki, and S. Kadota, "Selective antiproliferative activity of caffeic acid phenethyl ester analogues on highly liver-Metastatic murine colon 26-L5 carcinoma cell line," Bioorganic and Medicinal Chemistry, vol. 10, no. 10, pp. 3351-3359, 2002.

[105] P. Montpied, F. de Bock, G. Rondouin et al., "Caffeic acid phenethyl ester (CAPE) prevents inflammatory stress in organotypic hippocampal slice cultures," Molecular Brain Research, vol. 115, no. 2, pp. 111-120, 2003.

[106] Y.-J. Chen, M.-S. Shiao, and S.-Y. Wang, "The antioxidant caffeic acid phenethyl ester induces apoptosis associated with selective scavenging of hydrogen peroxide in human leukemic HL-60 cells," Anti-Cancer Drugs, vol. 12, no. 2, pp. 143-149, 2001.

[107] M. R. Fesen, Y. Pommier, F. Leteurtre, S. Hiroguchi, J. Yung, and K. W. Kohn, "Inhibition of HIV-1 integrase by flavones, caffeic acid phenethyl ester (CAPE) and related compounds," Biochemical Pharmacology, vol. 48, no. 3, pp. 595-608, 1994.

[108] W. Vasigara Singh, S. Subramaniam, S. Shyama, M. Jagadeesan, and C. S. Shyamala Devi, "Changes in erythrocyte membrane lipids in breast cancer after radiotherapy and chemotherapy," Chemotherapy, vol. 42, no. 1, pp. 65-70, 1996.

[109] J. H. Park, J. K. Lee, H. S. Kim et al., "Immunomodulatory effect of caffeic acid phenethyl ester in Balb/c mice," International Immunopharmacology, vol. 4, no. 3, pp. 429-436, 2004.
[110] A. Ilhan, M. Iraz, A. Gurel, F. Armutcu, and O. Akyol, "Caffeic acid phenethyl ester exerts a neuroprotective effect on CNS against pentylenetetrazol-induced seizures in mice," Neurochemical Research, vol. 29, no. 12, pp. 2287-2292, 2004.

[111] M. Yagmurca, H. Erdogan, M. Iraz, A. Songur, M. Ucar, and E. Fadillioglu, "Caffeic acid phenethyl ester as a protective agent against doxorubicin nephrotoxicity in rats," Clinica Chimica Acta, vol. 348, no. 1-2, pp. 27-34, 2004.

[112] E. Fadillioglu, E. Oztas, H. Erdogan et al., "Protective effects of caffeic acid phenethyl ester on doxorubicin-induced cardiotoxicity in rats," Journal of Applied Toxicology, vol. 24, no. 1, pp. 4752, 2004.

[113] E. Fadillioglu, H. Erdogan, M. Iraz, and M. Yagmurca, "Effects of caffeic acid phenethyl ester against doxorubicin-induced neuronal oxidant injury," Neuroscience Research Communications, vol. 33, no. 2, pp. 132-138, 2003.

[114] Y.-H. Lin, J.-H. Chiu, W.-S. Tseng, T.-T. Wong, S.-H. Chiou, and S.-H. Yen, "Antiproliferation and radiosensitization of caffeic acid phenethyl ester on human medulloblastoma cells," Cancer Chemotherapy and Pharmacology, vol. 57, no. 4, pp. 525-532, 2006.

[115] H. Ramazan Yilmaz, E. Uz, A. Altunbaşak, E. Sakalli, and N. Özçelik, "Anticlastogenic effect of caffeic acid phenethyl ester on cisplatin-induced chromosome aberrations in rat bone marrow cells," Toxicology and Industrial Health, vol. 26, no. 1, pp. 33-37, 2010.

[116] M. Iraz, E. Ozerol, M. Gulec et al., "Protective effect of caffeic acid phenethyl ester (CAPE) administration on cisplatininduced oxidative damage to liver in rat," Cell Biochemistry and Function, vol. 24, no. 4, pp. 357-361, 2006.

[117] H. R. Yilmaz, S. Sogut, B. Ozyurt et al., “The activities of liver adenosine deaminase, xanthine oxidase, catalase, superoxide dismutase enzymes and the levels of malondialdehyde and nitric oxide after cisplatin toxicity in rats: protective effect of caffeic acid phenethyl ester," Toxicology and Industrial Health, vol. 21, no. 3-4, pp. 67-73, 2005.

[118] E. Uzar, O. Sahin, H. R. Koyuncuoglu et al., "The activity of adenosine deaminase and the level of nitric oxide in spinal cord of methotrexate administered rats: protective effect of caffeic acid phenethyl ester," Toxicology, vol. 218, no. 2-3, pp. 125-133, 2006.

[119] F. Öktem, H. R. Yilmaz, F. Ozguner et al., "Methotrexateinduced renal oxidative stress in rats: the role of a novel antioxidant caffeic acid phenethyl ester," Toxicology and Industrial Health, vol. 22, no. 6, pp. 241-247, 2006.

[120] E. Uzar, H. R. Koyuncuoglu, E. Uz et al., "The activities of antioxidant enzymes and the level of malondialdehyde in cerebellum of rats subjected to methotrexate: protective effect of caffeic acid phenethyl ester," Molecular and Cellular Biochemistry, vol. 291, no. 1-2, pp. 63-68, 2006.

[121] A. Armagan, E. Uzar, E. Uz et al., "Caffeic acid phenethyl ester modulates methotrexate-induced oxidative stress in testes of rat," Human and Experimental Toxicology, vol. 27, no. 7, pp. 547552, 2008.

[122] E. Uz, F. Öktem, H. R. Yilmaz, E. Uzar, and F. Özgüner, "The activities of purine-catabolizing enzymes and the level of nitric oxide in rat kidneys subjected to methotrexate: protective effect of caffeic acid phenethyl ester," Molecular and Cellular Biochemistry, vol. 277, no. 1-2, pp. 165-170, 2005.

[123] T. Çakir, E. Özkan, E. Dulundu et al., "Caffeic acid phenethyl ester (CAPE) prevents methotrexate-induced 
hepatorenal oxidative injury in rats," Journal of Pharmacy and Pharmacology, vol. 63, no. 12, pp. 1566-1571, 2011.

[124] H. Özyurt, S. Söğüt, Z. Yildirim et al., "Inhibitory effect of caffeic acid phenethyl ester on bleomycine-induced lung fibrosis in rats," Clinica Chimica Acta, vol. 339, no. 1-2, pp. 65-75, 2004.

[125] A. Larki, A. A. Hemmati, A. Arzi, M. G. Borujerdnia, S. Esmaeilzadeh, and M. R. Z. Karami, "Regulatory effect of caffeic acid phenethyl ester on type I collagen and interferon-gamma in bleomycin-induced pulmonary fibrosis in rat," Research in Pharmaceutical Sciences, vol. 8, no. 4, pp. 243-252, 2013.

[126] A. A. Albukhari, H. M. Gashlan, H. A. El-Beshbishy, A. A. Nagy, and A. B. Abdel-Naim, "Caffeic acid phenethyl ester protects against tamoxifen-induced hepatotoxicity in rats," Food and Chemical Toxicology, vol. 47, no. 7, pp. 1689-1695, 2009.

[127] O. G. Yildiz, S. Soyuer, R. Saraymen, and C. Eroglu, "Protective effects of caffeic acid phenethyl ester on radiation induced lung injury in rats," Clinical and Investigative Medicine, vol. 31, no. 5, pp. E242-E247, 2008.

[128] Y.-Y. Lee, C.-L. Kao, P.-H. Tsai et al., "Caffeic acid phenethyl ester preferentially enhanced radiosensitizing and increased oxidative stress in medulloblastoma cell line," Child's Nervous System, vol. 24, no. 9, pp. 987-994, 2008.

[129] M.-F. Chen, P. C. Keng, P.-Y. Lin, C.-T. Yang, S.-K. Liao, and W.-C. Chen, "Caffeic acid phenethyl ester decreases acute pneumonitis after irradiation in vitro and in vivo," BMC Cancer, vol. 5, article 158, 2005.

[130] M.-F. Chen, C.-T. Wu, Y.-J. Chen, P. C. Keng, and W.-C. Chen, "Cell killing and radiosensitization by Caffeic Acid Phenethyl Ester (CAPE) in lung cancer cells," Journal of Radiation Research, vol. 45, no. 2, pp. 253-260, 2004. 

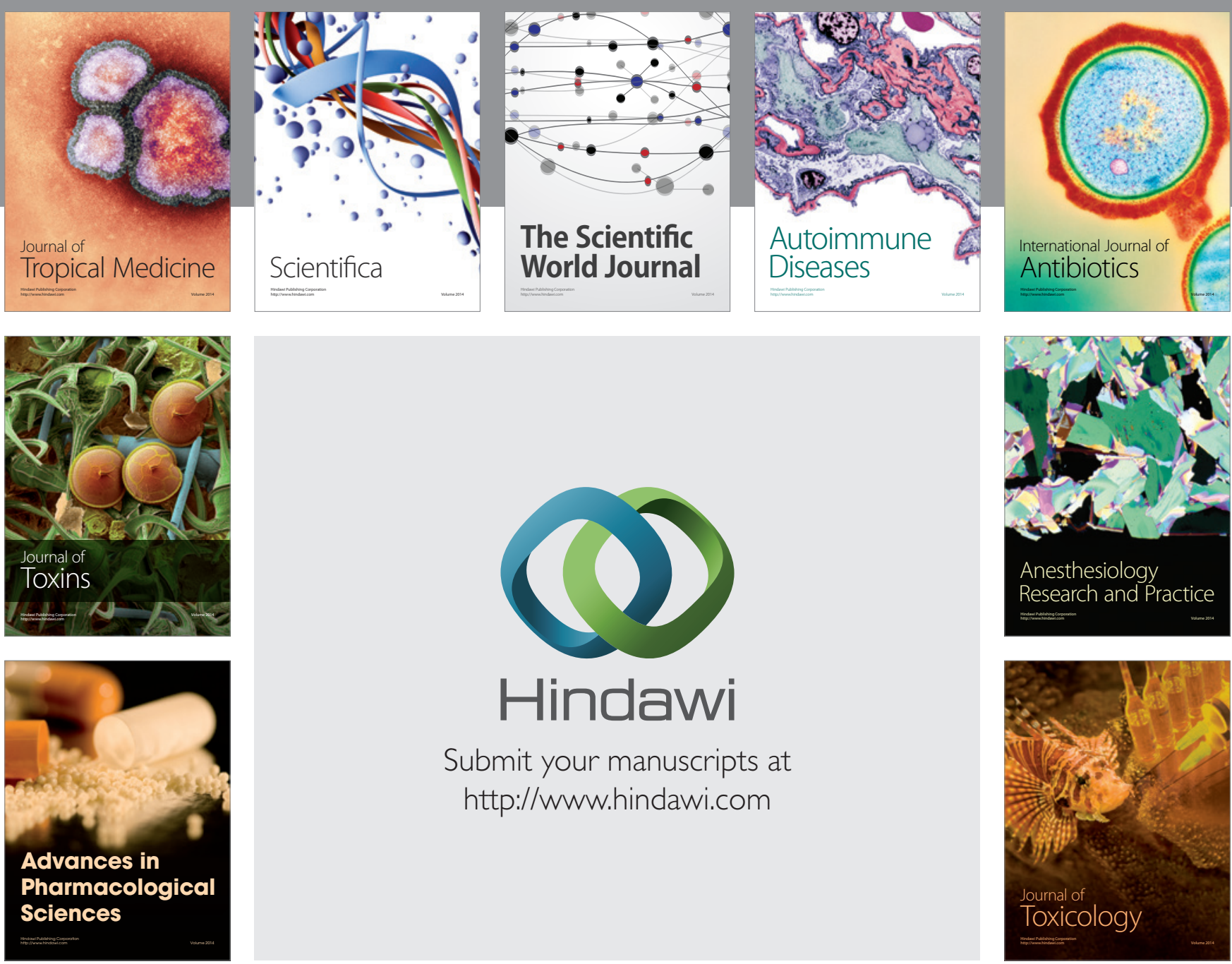

\section{Hindawi}

Submit your manuscripts at

http://www.hindawi.com
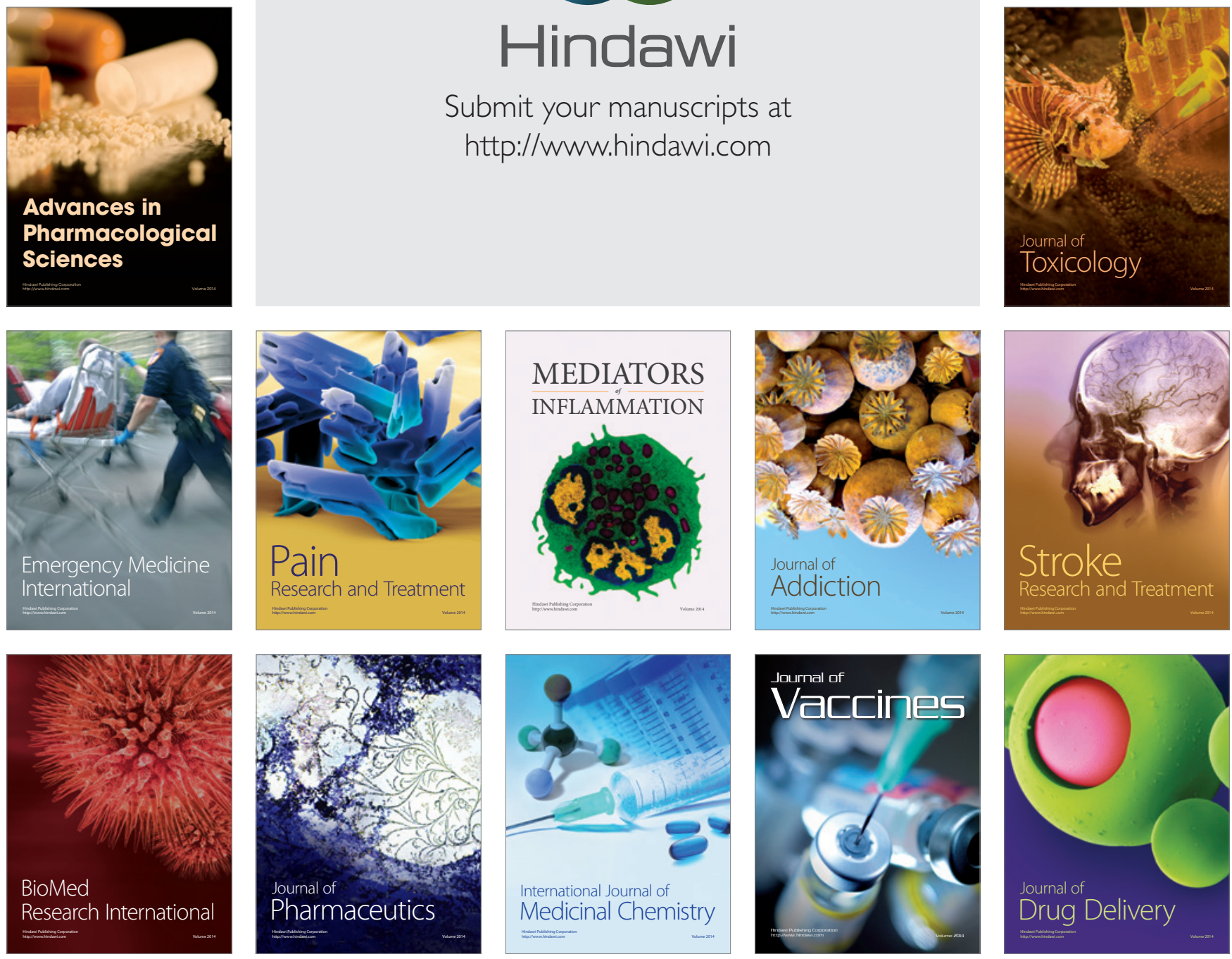